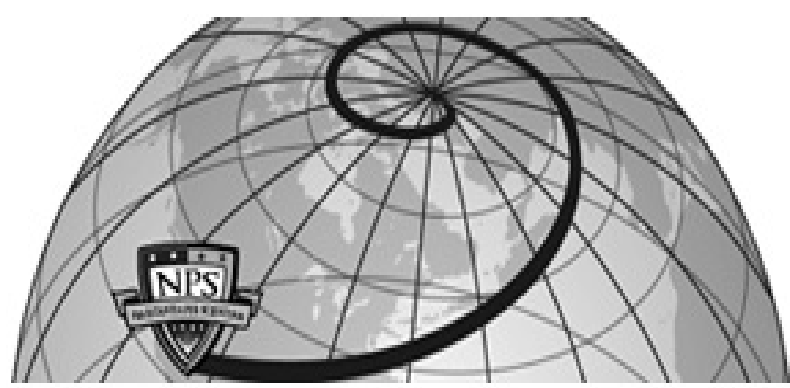

Calhoun: The NPS Institutional Archive DSpace Repository

Diel variation in beaked whale diving behavior

Baird, Robin; Webster, Daniel L.; Schorr, Gregory S.; McSweeney, Daniel J.

Monterey, California. Naval Postgraduate School

https://hdl.handle.net/10945/697

This publication is a work of the U.S. Government as defined in Title 17, United States Code, Section 101. Copyright protection is not available for this work in the United States.

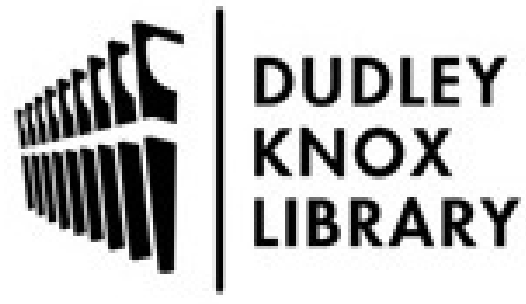

http://www.nps.edu/library
Calhoun is the Naval Postgraduate School's public access digital repository for research materials and institutional publications created by the NPS community. Calhoun is named for Professor of Mathematics Guy K. Calhoun, NPS's first appointed -- and published -- scholarly author.

Dudley Knox Library / Naval Postgraduate School 411 Dyer Road / 1 University Circle Monterey, California USA 93943 


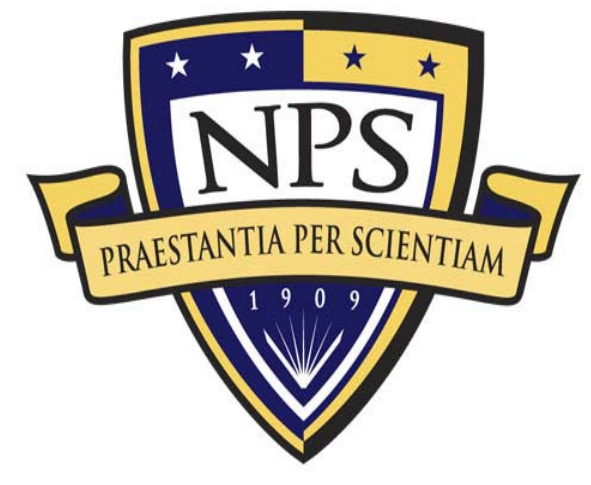

\author{
NAVAL \\ POSTGRADUATE \\ SCHOOL
}

\title{
MONTEREY, CALIFORNIA
}

\section{Diel Variation In Beaked Whale Diving Behavior} by

Robin Baird, Daniel L. Webster, Gregory S. Schorr, and Daniel J. McSweeney January 2008

Approved for public release; distribution is unlimited.

Prepared for: $\quad$ CNO/N45, Washington, D.C. 
THIS PAGE INTENTIONALLY LEFT BLANK 
NAVAL POSTGRADUATE SCHOOL

Monterey, California 93943

Daniel T. Oliver

Leonard A. Ferrari

President

Provost

This report was prepared for and funded by: CNO/N45, Washington, D.C.

Reproduction of all or part of this report is authorized.

This report was prepared by:

ROBIN BAIRD

Research Biologist

GREGORY S. SCHORR

Research Biologist

Reviewed by:

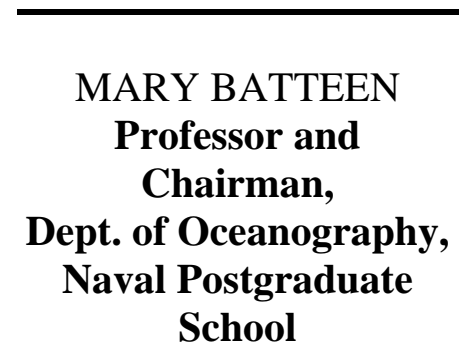

JOHN JOSEPH

Research Associate, Dept. of Oceanography, Naval Postgraduate School
MARY BATTEEN Professor and Chairman, Dept. of Oceanography, School
DANIEL L. WEBSTER Research Biologist

DANIEL J. McSWEENEY Research Biologist

Released by: 
THIS PAGE INTENTIONALLY LEFT BLANK 


\section{REPORT DOCUMENTATION PAGE}

Form Approved OMB No. 0704-0188

Public reporting burden for this collection of information is estimated to average 1 hour per response, including the time for reviewing instruction, searching existing data sources, gathering and maintaining the data needed, and completing and reviewing the collection of information. Send comments regarding this burden estimate or any other aspect of this collection of information, including suggestions for reducing this burden, to Washington headquarters Services, Directorate for Information Operations and Reports, 1215 Jefferson Davis Highway, Suite 1204, Arlington, VA 22202-4302, and to the Office of Management and Budget, Paperwork Reduction Project (0704-0188) Washington DC 20503.

\begin{tabular}{|c|c|c} 
1. AGENCY USE ONLY (Leave blank) & $\begin{array}{c}\text { 2. REPORT DATE } \\
\text { January } 2008\end{array}$ & $\begin{array}{c}\text { 3. REPORT TYPE AND DATES COVERED } \\
\text { Technical Report, } 2002-2007\end{array}$ \\
\hline
\end{tabular}

4. TITLE AND SUBTITLE: Title (Mix case letters) $\quad$ 5. FUNDING NUMBERS

Diel Variation in Beaked Whale Diving Behavior $\quad$ N6227106MPRR403

6. AUTHOR(S) Robin Baird, Daniel L. Webster, Gregory S. Schorr, and Daniel J. McSweeney

7. PERFORMING ORGANIZATION NAME(S) AND ADDRESS(ES)

1. Cascadia Research Collective, Olympia, WA 98501

2. Wild Whale Research Foundation, Holualoa, HI 96725

8. PERFORMING

ORGANIZATION REPORT

NUMBER

9. SPONSORING / MONITORING AGENCY NAME(S) AND ADDRESS(ES)

Sponsoring Agency: CNO/N45, Washington, D.C.

Monitoring Agency: Department of Oceanography, Naval Postgraduate School, 833

Dyer Road, Monterey, CA 93943-5122

11. SUPPLEMENTARY NOTES The views expressed in this technical report are those of the authors and do not reflect the official policy or position of the Department of Defense or the U.S. Government.

\begin{tabular}{l|l} 
12a. DISTRIBUTION / AVAILABILITY STATEMENT & 12b. DISTRIBUTION CODE
\end{tabular}

Approved for public release; distribution is unlimited.

\section{ABSTRACT (maximum 200 words)}

Diel variation in beaked whale diving behavior is investigated using data from time-depth recorders deployed on six Blainville's (Mesoplodon densirostris) and two Cuvier's (Ziphius cavirostris) beaked whales. Deep foraging dives $(>800 \mathrm{~m})$ occurred at similar rates during the day and night for Blainville's beaked whales $\left(\right.$ day $_{\text {mean }}=0.38 \mathrm{~h}^{-1}$; night $\left._{\text {mean }}=0.46 \mathrm{~h}^{-1}\right)$, and there were no significant diel differences in depths, durations, ascent or descent rates for deep dives. Dives to mid-water depths $(100-600 \mathrm{~m})$ occurred significantly more often during the day (mean=1.59 $\mathrm{h}^{-1}$ ) than at night $\left(\right.$ mean $\left.=0.26 \mathrm{~h}^{-1}\right)$. Series of progressively shallower "bounce" dives were only documented following deep, long dives made during the day, while at night whales spent more time in shallow (<100 m) depths. Significantly slower ascent than descent rates were found following deep foraging dives both during the day and night. Similar patterns were found for the Cuvier's beaked whales. These results suggest that so-called "bounce" dives do not serve a physiological function, although the slow ascents may. This diel variation in behavior suggests that beaked whales may spend less time in surface waters during the day to avoid near-surface, visually-oriented predators, such as large sharks or killer whales (Orcinus orca).

14. SUBJECT TERMS Beaked whale, diel diving behavior, Blainville’s beaked whale, Cuvier's beaked whale, Ziphius cavirostris, Mesoplodon densirostris, marine mammals, “bounce” dives.

17. SECURITY CLASSIFICATION OF REPORT

Unclassified
18. SECURITY CLASSIFICATION OF THIS PAGE
19. SECURITY CLASSIFICATION OF ABSTRACT Unclassified
15. NUMBER OF PAGES 32 16. PRICE CODE 20. LIMITATION OF ABSTRACT UU 
THIS PAGE INTENTIONALLY LEFT BLANK 


\section{$\underline{\underline{\text { Contents }}}$}

List of Tables $\quad$ ii

List of Figures $\quad$ ii

$\begin{array}{ll}\text { Title Page } & 1\end{array}$

$\begin{array}{ll}\text { Abstract } & 2\end{array}$

Introduction 3

$\begin{array}{ll}\text { Methods } & 6\end{array}$

$\begin{array}{ll}\text { Results } & 7\end{array}$

$\begin{array}{ll}\text { Discussion } & 9\end{array}$

$\begin{array}{ll}\text { Acknowledgments } & 14\end{array}$

$\begin{array}{ll}\text { References } & 14\end{array}$

$\begin{array}{ll}\text { Tables } & 19\end{array}$

$\begin{array}{ll}\text { Figures } & 20\end{array}$

Initial Distribution List $\quad 22$ 


\section{List of Tables}

Table 1: Comparison of diving parameters for Blainville’s beaked whales.

Table 2: Comparison of diving parameters for Cuvier's beaked whales.

\section{List of Figures}

Figure 1: $\quad$ Cumulative percentage of time at or less than specified depths during the day or at night for all six Blainville's beaked whales with both day- and night-time data.

Figure 2: $\quad$ Cumulative percentage of time at or less than specified depths during the day or at night for all two Cuvier's beaked whales with both day- and night-time data. 


\title{
DIEL VARIATION IN BEAKED WHALE DIVING BEHAVIOR
}

\author{
Robin W. Baird ${ }^{1}$, Daniel L. Webster ${ }^{2}$, Gregory S. Schorr ${ }^{1}$, Daniel J. McSweeney ${ }^{2}$ \\ ${ }^{1}$ Cascadia Research Collective, 2181/2 W. $4^{\text {th }}$ Avenue, Olympia, WA 98501, USA \\ rwbaird@cascadiaresearch.org \\ ${ }^{2}$ Wild Whale Research Foundation, Box 139, Holualoa, HI 96725, USA
}

November 3, 2007

\author{
Final report prepared under \\ Contract No. AB133F-06-CN-0053 to \\ Cascadia Research Collective, Olympia, Washington, \\ from the Southwest Fisheries Science Center, \\ National Marine Fisheries Service, La Jolla, California
}


Abstract: We investigate diel variation in beaked whale diving behavior using data from time-depth recorders deployed on six Blainville's (Mesoplodon densirostris) beaked whales (126 hours day; 129 hours night) and two Cuvier's (Ziphius cavirostris) beaked whales (19 hours day; 15 hours night). Deep foraging dives (>800 $\mathrm{m}$ ) occurred at similar rates during the day and night for Blainville's beaked whales (day mean $=0.38 \mathrm{~h}^{-1}$; night mean $=0.46 \mathrm{~h}^{-1}$ ), and there were no significant diel differences in depths, durations, ascent rates or descent rates for deep dives. Dives to mid-water depths (100-600 m) occurred significantly more often during the day (mean $=1.59 \mathrm{~h}^{-1}$ ) than at night $\left(\right.$ mean $\left.=0.26 \mathrm{~h}^{-1}\right)$. Series of progressively shallower "bounce" dives were only documented to follow the deep, long dives made during the day; at night whales spent more time in shallow $(<100 \mathrm{~m})$ depths. Significantly slower ascent rates than descent rates were found following deep foraging dives both during the day and night. Similar patterns were found for the Cuvier's beaked whales. Our results suggest that so-called "bounce" dives do not serve a physiological function, although the slow ascents may. This diel variation in behavior suggests that beaked whales may spend less time in surface waters during the day to avoid near-surface, visually-oriented predators such as large sharks or killer whales (Orcinus orca). 


\section{Introduction}

Diel differences of behavior are pervasive for terrestrial animals, with species typically active either during the day or at night depending on whether their sensory systems are adapted for best performance in light or dark regimes. Even for species able to function equally well in both light and dark conditions, diel variation in behavior may occur in response to changes in predation pressure, availability of food, or potentially as a response to anthropogenic activities that exhibit a diel pattern (Lima and Bednekoff 1999; Railsback et al. 2005). Many species of odontocete cetaceans feed deep in the water column, relying primarily on echolocation, rather than vision, to detect prey. Yet diel vertical movements have been documented for several species of odontocetes, in most cases likely reflecting vertical movements of their prey associated with changing time of day. Many species of zooplankton are thought to exhibit diel vertical migrations in response to predation pressure; many are found at depths during the day where low light levels reduce the risk from visual predators (Bollens et al. 1992). Predators of zooplankton may either follow their prey's diel migration, or may remain at shallower depths in the water column and feed at night when zooplankton rise towards the surface. Higher trophic level predators may similarly follow their prey's vertical movements, resulting in similar vertical movements of some marine top predators (e.g., Croxall et al. 1985; Eckert et al. 1989; Watanabe et al. 2006). At least some of the diel patterns documented for cetaceans can be related to such corresponding vertical movements of zooplankton and associated organisms. Pantropical spotted dolphins (Stenella attenuata) in Hawai'i dive the deepest at sunset, apparently to meet the rising layer of diel migrators, and forage more at night than during the day, when prey are closer to the surface and easier to obtain (Baird et al. 2001). Spinner dolphins (S. longirostris) in Hawai'i spend 
the day resting in shallow waters and forage at night on prey that exhibit both vertical and horizontal migrations (Norris et al. 1994; Benoit-Bird and Au 2003). Long-finned pilot whales (Globicephala melas) in the Mediterranean Sea made their deepest dives around sunset, and swim speeds on deeper dives were greater than during shallower dives, suggesting increased foraging (Baird et al. 2002). Short-finned pilot whales (G. macrorhynchus) off the Canary Islands spent more time foraging at night near the surface, based on acoustic tags recording echolocation clicks and dive depths (Aguilar de Soto 2006). Fisheating killer whales (Orcinus orca) in the nearshore waters of the temperate eastern North Pacific also show diel changes in diving behavior, with shallower dives at night (Baird et al. 2005). Swim speed is also lower at night however, possibly because of the importance of vision in prey capture for this species (Baird et al. 2005).

Diel variation in cetacean behavior may have a variety of implications for management of human interactions, and understanding why this variation occurs is critical to assessing its relevance to management. Diel variation in migration rates or distance from shore could influence shore-based population estimates (Perryman et al. 1999). If individuals rest or feed at or near the surface only during certain times of the day, they may be more susceptible to vessel impact or disturbance from vessel traffic during those periods (e.g., Danil et al. 2005). Conversely, during such times of high surface activity, individuals may be more readily detected if visual detection is important for mitigating impacts due to seismic surveys, vessel traffic, or naval sonar use (e.g., Anonymous 2006). The ability to detect vocalizing individuals using passive acoustics (e.g., Moretti et al. 2006) could also vary by time of day if individuals only vocalize when foraging and diving deep (e.g., Johnson et al. 2004), and foraging behavior occurs more during the day or night. Species that are caught in deep- 
set nets or long-lines may also be more susceptible to fisheries interactions at certain times of the day if deep foraging dives follow a diel cycle.

Beaked whales (Family Ziiphidae) make among the longest and deepest dives of any cetaceans, with at least some species foraging at depths of $1,000 \mathrm{~m}$ or more during the day (Hooker and Baird 1999; Baird et al. 2006a; Tyack et al. 2006). Published studies have not addressed diel variation in beaked whale diving behavior in detail, as sample sizes of night-time dive data have been limited. Deep dives have been documented both in the day and at night (Hooker and Baird 1999; Baird et al. 2006a); however, based on small sample sizes, Baird et al. (2006a) noted that both Cuvier's (Ziphius cavirostris) and Blainville's (Mesoplodon densirostris) beaked whales spent more time in near-surface waters at night. With only a single day/night record for each species no analyses of diel patterns were undertaken.

Among the cetaceans, beaked whales are unusual in their apparent susceptibility to injury or death associated with high-intensity mid-frequency naval sonars (e.g., Balcomb and Claridge 2001; Cox et al. 2006). The pathogenic mechanisms resulting in injury or death are unknown (Rommell et al. 2006; Cox et al. 2006), but several aspects of their diving behavior have been suggested as potentially related to such susceptibility. Deep foraging dives, often exceeding an hour in duration, have substantially slower ascents than descents, and have been reported to be followed by an extended period of progressively shallower "bounce" dives (Baird et al. 2006a; Tyack et al. 2006). It has been questioned whether these "bounce" dives may serve as recompression dives to reduce the likelihood of gas embolisms (Cox et al. 2006, although see Zimmer and Tyack 2007). The proportion of time individuals spend near the surface, in 
depths where nitrogen may build up within tissues, may affect their susceptibility to anthropogenic impacts (Zimmer and Tyack 2007).

Detecting beaked whales, either visually or acoustically, is becoming increasingly important in association with naval exercises or sonar use, to try to mitigate impacts (see e.g., Anonymous 2006). Given the long dive times and low surfacing profiles, detecting beaked whales visually is problematic, to say the least (Barlow and Gisiner 2006). Passive acoustic detection is also challenging: Johnson et al. (2004) and Tyack et al. (2006) documented that Cuvier's and Blainville's beaked whales produce sounds primarily when foraging at depths (e.g., below approximately $400 \mathrm{~m}$ ), thus limiting detection with surface hydrophones. Active acoustic detection may also be possible (e.g., Hooker and Baird 1999; Ellison and Stein 2001), although detection at great depths $(\mathrm{e} . \mathrm{g} .,>400 \mathrm{~m})$ has not been verified. For all of these detection issues, understanding diel patterns of vertical use of the water column is critical. Examining this variation in behavior may also shed light on aspects of the diving behavior of beaked whales that may put them more at risk of anthropogenic impacts. We examine diel patterns of diving behavior with a sample of day/night dive data from two species, Cuvier's and Blainville's beaked whales, tagged with time-depth recorders off the west coast of the island of Hawai'i.

\section{Methods}

Field work was undertaken off the west side of the island of Hawai' $i$ in each year from 2002 through 2007. Methods have been described in detail in Baird et al. (2006a), and are summarized briefly here. Suction-cup attached tags containing an Mk9 time-depth recorder (Wildlife Computers, Redmond, Washington) and a VHF radio transmitter (ATS, Isanti, Minnesota) were attached to beaked 
whales using either a crossbow (RX-150, Barnett International, Odessa Florida) or a $5.2 \mathrm{~m}$ carbon-fiber pole. All tagged individuals were photographed and individually photo-identified following the methods of McSweeney et al. (2007). Tags were recovered using signals from the VHF transmitter.

Time of sunset and sunrise were used to delineate day- and night-time data. For individuals whose tags stayed on for more than one day/night cycle, dive statistics were calculated separately for each day-time and night-time period, and mean values for each of the dive statistics (for "day" or "night") were used in statistical comparisons among individuals. Dive rates (\# dives $\mathrm{h}^{-1}$ ) were calculated for dives with a maximum depth of 100-600 $\mathrm{m}$ and for dives $>800 \mathrm{~m}$. Dive statistics (durations, maximum depths, ascent and descent rates) were calculated as per Baird et al. (2006a) for dives $>800 \mathrm{~m}$. We also compared the proportion of time spent between 22 and $72 \mathrm{~m}$ in depth, the depths at which Zimmer and Tyack (2007) predict to be most important for nitrogen uptake into tissues. Statistical analyses were conducted with Minitab 13 using paired $t$ tests, with each individual's day-time and night-time values treated as a pair. Thus the sample size for all statistical tests was the number of individuals tagged. Percentage change from day to night was calculated as: ([Value night value day]/value night) * 100.

\section{Results}

Dive data were obtained from two Cuvier's and nine Blainville's beaked whales. Tags deployed on both of the Cuvier's beaked whales (one in November 2004 and one in November 2006) and six of the Blainville's beaked whales (one in September 2004, three in April 2006 and two in November 2006) were applied in the day and remained on into the night. One of the six Blainville's beaked 
whales was tagged twice during the same encounter: the initial tag deployed remained on longer than the second tag, so only data from the initial tag deployed were used. Data from the two individuals tagged in 2004 were previously analyzed by Baird et al. (2006a). Tag attachments for Blainville's beaked whales that remained on into the night (two adult males, three adult females, and one adult female/large subadult) ranged from 18.63 to 78.32 hours $($ sum $=253.7 \mathrm{~h}:$ day- $125.0 \mathrm{~h}$; night-- $128.7 \mathrm{~h})$, and for Cuvier's beaked whales (one adult female, one adult male) were for 9.75 and 34.18 hours (sum $=43.9 \mathrm{~h}$ : day-- $23.8 \mathrm{~h}$; night-- $20.1 \mathrm{~h}$ ). All data obtained were from different individuals (based on distinctive markings; see McSweeney et al. 2007).

For Blainville's beaked whales, there were no significant day/night differences in the rate of deep ( $>800 \mathrm{~m}$ ) dives, or the mean duration, mean depth, maximum duration, maximum depth, ascent rate, or descent rate of deep dives (Table 1). For deep dives $(>800 \mathrm{~m})$, descent rates were significantly greater than ascent rates both during the day $(p<0.001)$ and at night $(p=0.001)$, with average ratios of descent to ascent rates of 2.22 during the day and 1.85 at night. Dives to mid-water depths (100-600 m) occurred approximately six times more frequently during the day than at night (paired t-test, $p=0.001$ ). The proportion of time spent at depths $<50 \mathrm{~m}$, as well as the longest continuous period of time spent at depths $<50 \mathrm{~m}$, were significantly greater during the night than during the day $\left(p^{\prime} s=0.004\right.$ and $\odot .036$, respectively, Table 1 , Fig. 1).

While sample size precluded statistical testing for Cuvier's beaked whales, the same trends in diving parameters between the day and night were found for that species (Table 2, Fig. 2), with similar effect sizes. The ratios of descent rates to ascent rates for deep $(>800 \mathrm{~m})$ dives were similar to those of 
Blainville's beaked whales (2.36 during the day, 1.86 at night). Dives to midwater depths (100-600 m) occurred 4.5 times more frequently during the day than at night for Cuvier's beaked whales. While more time was spent $<50 \mathrm{~m}$ during the night (42.9\% versus $12.7 \%$ ), more was also spent below $500 \mathrm{~m}$ at night (43.0\%) than during the day (35.4\%).

\section{Discussion}

Cuvier's and Blainville's beaked whales were documented diving to depths of 1484 and $1599 \mathrm{~m}$ and remaining submerged for up to 94.58 and 83.38 minutes, respectively (Table 1 ). Both species are thought to forage primarily on deep (e.g., >800 m) dives (Baird et al. 2006a; Tyack et al. 2006). In general, at night individuals of both species spent a greater proportion of their time below $500 \mathrm{~m}$ in depth and had higher rates of deep (>800 $\mathrm{m}$ ) dives than they did during the day (Tables 1, 2), although these differences were not statistically significant. The depths and durations of these deep dives were also similar between the day and night, suggesting that both species forage as much during the night as they do during the day. This also indicates that the prey of both species of beaked whales in Hawaiian waters either do not exhibit diel vertical migrations, or that the whales switch prey species at night to deeper-water species. Little is known of the diet of either species in Hawaiian waters, although they are thought to feed primarily on deep-water squid (for Cuvier's) and deep-water squid and fish (for Blainville's) (MacLeod et al. 2003; Santos et al. 2007). In our efforts only a single prey item, a squid (Histioteuthis hoylei), has been recovered from foraging Cuvier's beaked whales (Baird,

unpublished). Diel vertical migrations of $H$. hoylei have not been reported, and other species of Histioteuthis are known to remain at depth both during the day and at night (Watanabe et al. 2006). Our finding of deep foraging dives 
occurring roughly equally during the day and night suggests that passive acoustic detection of vocalizing Cuvier's and Blainville's beaked whales (e.g., Moretti et al. 2006), should be similarly effective both during the day and night. While our results are only from a single study area and our sample size is small, diving patterns of these two species appear very stereotypic; dive patterns from our study are very similar to the dive patterns that Tyack et al. (2006) report for the same species from studies in the Mediterranean Sea and Canary Islands. Regardless, more long-duration deployments on Cuvier's beaked whales are required, given that our results for that species are based on only two individuals.

Despite the similar rates of deep dives both during the day and at night, there were diel differences in diving behavior (Fig. 1, Fig. 2). During the night both species spent more time in near-surface $(<50 \mathrm{~m})$ waters. Although our sample size is small, in the case of Cuvier's beaked whale this difference was striking (12.7\% during the day versus $42.9 \%$ at night), despite the increased time spent below $500 \mathrm{~m}$ in depth (Table 2). The tendency for both species to spend more time either near the surface or at depths below $500 \mathrm{~m}$ reflects the almost complete absence of what has been termed "bounce" dives (Cox et al. 2006) following the long, deep dives during the night. Given this, it seems unlikely that such dives serve a physiological function. Zimmer and Tyack (2007) noted that, in theory, all air spaces of beaked whales should have collapsed at depths closer to $70-100 \mathrm{~m}$, and thus these so-called bounce dives were unlikely to serve a re-compression function as they do for human divers. Ascent rates of dives greater than $800 \mathrm{~m}$ were significantly slower than descent rates both during the day and at night, suggesting that the slow ascents serve some physiological purpose. However, most of the reduction in ascent rates occurs at depths below the theoretical depth of lung collapse (Baird et al. 2006a; Tyack et al. 2006); 
thus the lower ascent rates may not function in reducing the nitrogen saturation in their bodies. The increased presence of Blainville's and Cuvier's beaked whales at shallower depths of the water column during the night should increase the likelihood of their detection using active acoustic methods, such as those employed in association with the U.S. Navy's Low-Frequency Active (LFA) sonar (Ellison and Stein 2001).

If beaked whales are feeding at depth at similar rates during the night as during the day, why would they spend less time in mid-water depths (100-600 m) and more time at shallow $(<50 \mathrm{~m})$ depths during the night? Based on studies using acoustic tags that detect echolocation clicks (Johnson et al. 2004; Tyack et al. 2006), and the shape of dives $<600 \mathrm{~m}$ (i.e., typically flat-bottomed Ushape or parabolic dives; Baird unpublished), it appears that foraging is unlikely to occur during either shallow $(<50 \mathrm{~m})$ or mid-water $(100-600 \mathrm{~m})$ dives. One possibility is that predation pressure is higher in near-surface waters during the day than at night, and that beaked whales modify their diving behavior in relation to predation risk (Heithaus and Frid 2003). Predators of beaked whales may include both large sharks (Long and Jones 1996) and killer whales (Mead 1989; Notarbartolo-di-Sciara 1987), and beaked whales in Hawaiian waters are also regularly bitten by parasitic cookie-cutter sharks of the genus Isistius (McSweeney et al. 2007). Cookie-cutter sharks are thought to exhibit diel vertical migrations, spending time near the surface at night; so the beaked whale dive patterns we've documented may bring them into more regular contact with cookie-cutter sharks than if they remained at mid-water depths during the day. At least three species of large predatory sharks that might fatally attack beaked whales, tiger (Galeocerdo cuvier), Galapagos (Carcharhinus galapagensis) and white (Carcharodon carcharias) sharks (Wetherbee et al. 1996; Boustany et al. 2002; weng et al. 2007), are found in Hawaiian waters. Whether any of these 
species attack adult beaked whales is unknown, but Long and Jones (1996) provide evidence of approximately 5-m long white sharks attacking a juvenile ( $3 \mathrm{~m}$ long) Cuvier's beaked whale and Stejneger's beaked whale (M. stejnegeri) off California. Shark attacks do occur on beaked whales in Hawai'i: McSweeney et al. (2007) noted scars on both a Cuvier's and a Blainville's beaked whale from attacks by large sharks. While little is known of the vertical movements of any of these species in Hawaiian waters, they are thought to be predominantly nearsurface (e.g., top few hundred meters) predators (e.g., Holland et al. 1999; Papastamatiou et al. 2006; Weng et al. 2007). Based in part on methods used to study shark foraging and the inherent difficulties of studying predation of intermittent feeders such as sharks, there is uncertainty regarding whether large sharks are more or less likely to attack large marine mammals during the day or at night. Much of what is known about diel feeding in sharks comes from catch rates using baited hooks, a scenario quite dissimilar to detection and capture of a large free-swimming cetacean. In addition, the sharks in question exhibit a shift in diet with size, with only larger individuals feeding on marine mammals (Lowe et al. 1996; Tricas and McCosker 1984). Tiger sharks do forage both during the day and at night, but catch rates have been reported to be significantly lower at night off Australia (Heithaus 2001). Based on examination of the visual system and departure times from baits, white sharks are thought to be primarily a diurnal predator (Gruber and Cohen 1985; Strong 1996). Given the abilities of cetaceans to detect potential predators using both vision and echolocation, and the importance of vision in prey capture for sharks (Strong 1996), white sharks are thought to use stealth in attacking cetacean prey (Long and Jones 1996). Clearly however, more information is needed on diel foraging behavior of large sharks in Hawaiian waters to better understand the relationship between shark behavior and beaked whale diving patterns. 
Killer whales are rare in Hawaiian waters, but are thought to feed at least in part on marine mammals there (Baird et al. 2006b). Both fish-eating and mammal-eating killer whales primarily spend their time in the top 100-200 m of the water column, and both appear to exhibit reduced activity at night, possibly reflecting the importance of vision in prey capture for this species (Baird et al. 2005; Baird unpublished). It has been suggested that predation avoidance may also be the reason why Cuvier's and Blainville's beaked whales vocalize only at depths below approximately $400 \mathrm{~m}$ (Tyack et al. 2006), and we suggest that beaked whales spend more time in near-surface waters at night due to reduced predation pressure.

In assessing factors that influence the susceptibility of beaked whales to impacts from mid-frequency sonar, Zimmer and Tyack (2007) discuss how beaked whales might react to sounds of predators such as killer whales. If detected acoustically at a distance, beaked whales might modify their diving patterns to increase horizontal displacement away from the potential threat, thus potentially increasing the proportion of time spent at shallow depths (e.g., 22$72 \mathrm{~m}$ ) where uptake of nitrogen into the body is more likely to occur. If beaked whales do not discriminate between killer whale calls and high-intensity midfrequency sonars, and act in a similar way to both, such a reaction to midfrequency sonar could put beaked whales at more risk of decompression-like symptoms as found in several strandings (e.g., Jepson et al. 2003; Fernandez et al. 2005). Mid-frequency sonar associated with naval exercises may continue for an extended period and propagate for a greater distance than the higher frequency (and lower intensity) calls of killer whales, thus potentially eliciting a response for an extended period (Zimmer and Tyack 2007). If predation pressure by killer whales is lower at night than during the day, it is 
possible that beaked whales may react less to killer whale sounds at night, and potentially to mid-frequency sonar use at night. Sound playback experiments currently being undertaken with beaked whales (Southall et al. 2007) could be used to test this supposition.

\section{Acknowledgments}

We thank the Southwest Fisheries Science Center and U.S. Navy (N45) for primary financial support, and the Wild whale Research Foundation for logistical support. A large number of individuals assisted in the field, but we would particularly like to thank Sarah Courbis, Annie Douglas, Megan Ferguson, Allan Ligon, Jens Koblitz, Sabre Mahaffy, Erin Oleson, and Jonathan Whitney. Sabre Mahaffy compared photographs of all tagged individuals to our catalogs. Discussions with Mike Heithaus and Yannis Papastamatiou regarding shark foraging and William walker regarding squid diel movements were helpful. John Calambokidis and Gretchen Steiger made helpful comments on the report. Research was undertaken under NMFS Scientific Research Permit No. 731 issued to RWB.

\section{References}

Aguilar de Soto, N. 2006. Acoustic and diving behaviour of the short finned pilot whales (Globicephala macrorhynchus) and Blainville's beaked whale (Mesoplodon densirostris) in the Canary Islands. Implications on the effects of man-made noise and boat collisions. PhD Thesis, Universidad de La Laguna, Spain.

Anonymous. 2006. 2006 Supplement to the 2002 Rim of the Pacific (RIMPAC) Programmatic Environmental Assessment. Available from http://WWW.nmfs.noaa.gov/pr/pdfs/permits/rimpac_ea.pdf (accessed August $2006)$.

Baird, R.W., A.D. Ligon, S.K. Hooker, and A.M. Gorgone. 2001. Subsurface and nighttime behaviour of pantropical spotted dolphins in Hawai’i. Can. J. Zool. 79: 988-996.

Baird, R.W., J.F. Borsani, M.B. Hanson, and P.L. Tyack. 2002. Diving and night-time behavior of long-finned pilot whales in the Ligurian Sea. Mar. Ecol. Prog. Ser. 237: 301-305.

Baird, R.W., M.B. Hanson, and L.M. Dill. 2005. Factors influencing the diving behaviour of fish-eating killer whales: sex differences and diel and interannual variation in diving rates. Can. J. Zool. 83: 257-267. 
Baird, R.W., D.L. Webster, D.J. McSweeney, A.D. Ligon, G.S. Schorr, and J. Barlow. 2006a. Diving behaviour of Cuvier's (Ziphius cavirostris) and Blainville's (Mesoplodon densirostris) beaked whales in Hawai'i. Can J. Zool. 84: 1120-1128.

Baird, R.W., D.J. McSweeney, C. Bane, J. Barlow, D.R. Salden, L.K. Antoine, R.G. LeDuc, and D.L. Webster. 2006b. Killer whales in Hawaiian waters: information on population identity and feeding habits. Pac. Sci. 60: $523-530$.

Balcomb, K.C., and D.E. Claridge. 2001. A mass stranding of cetaceans caused by naval sonar in the Bahamas. Bahamas J. Sci. 5: 1-12.

Barlow, J., and R. Gisiner. 2006. Mitigating, monitoring and assessing the effects of anthropogenic sound on beaked whales. J. Cetacean Res. Manage. 7: 239-249.

Benoit-Bird, K.J., and W.W.L. Au. 2003. Prey dynamics affect foraging by a pelagic predator (Stenella longirostris) over a range of spatial and temporal scales. Behav. Ecol. Sociobio. 53: 364-373.

Bollens, S.M., B.W. Frost, D.S. Thoreson, and S.J. Watts. 1992. Diel vertical migration in zooplankton: field evidence in support of the predator avoidance hypothesis. Hydrobiologia 234: 33-39.

Boustany, A.M., S.F. Davis, P. Pyle, S.D. Anderson, B.J. Le Boeuf, and B.A. Block. 2002. Expanded niche for white sharks. Nature 415: 35-36.

Cox, T.M., T.J. Ragen, A.J. Read, E. Vos, R.W. Baird, K. Balcomb, J. Barlow, J. Caldwell, T. Cranford, L. Crum, A. D'Amico, G. D'Spain, A. Fernández, J. Finneran, R. Gentry, W. Gerth, F. Gulland, J. Hildebrand, D. Houser, T. Hullar, P.D. Jepson, D. Ketten, C.D. MacLeod, P. Miller, S. Moore, D. Mountain, D. Palka, P. Ponganis, S. Rommel, T. Rowles, B. Taylor, P. Tyack, D. Wartzok, R. Gisiner, J. Mead, and L. Benner. 2006. Understanding the impacts of anthropogenic sound on beaked whales. $J$. Cetacean Res. Manage. 7: 177-187.

Croxall, J.P., I. Everson, G.L. Kooyman, C. Ricketts, and R.W. Davis. 1985. Fur seal diving behaviour in relation to vertical distribution of krill. J. Anim. Ecol. 54: 1-8.

Danil, K., D. Maldini, and K. Marten. 2005. Patterns of use of Maku'a Beach, 0‘ahu, Hawai'i, by spinner dolphins (Stenella longirostris) and potential effects of swimmers on their behavior. Aquat. Mamm. 31: 403-412.

Eckert, S.A., K.L. Eckert, P. Ponganis, and G.L. Kooyman. 1989. Diving and foraging behavior of leatherback sea turtles (Dermochelys coriacea). Can. J. Zool. 67: 2834-2840.

Ellison, W.T., and P.J. Stein. 2001. SURTASS LFA high frequency marine mammal monitoring (HF/M3) sonar: system description and test \& evaluation. Report prepared under U.S. Navy Contract N66604-98-D-5725. 
Fernandez, A., J.F. Edwards, F. Rodriguez, A. Espinosa de los Monteros, P. Herraez, P. Castro, J.R. Jaber, V. Martin, and M. Arbelo. 2005. "Gas and fat embolic syndrome" involving a mass stranding of beaked whales (Family Ziphiidae) exposed to anthropogenic sonar signals. Vet. Path. 42: $446-457$.

Gruber, S.H., and J.L. Cohen. 1985. Visual system of the white shark, Carcharodon carcharias, with emphasis on retinal structure. Mem. Southern Cal. Acad. Sci. 9: 61-72.

Heithaus, M.R. 2001. The biology of tiger sharks, Galeocerdo cuvier, in Shark Bay, Western Australia: sex ratio, size distribution, diet, and seasonal changes in catch rates. Env. Biol. Fish. 61: 25-36.

Heithaus, M.R., and A. Frid. 2003. Optimal diving under the risk of predation. J. Theor. Biol, 223: 79-92.

Holland, K.N., B.M. Wetherbee, C.G. Lowe, and C.G. Meyer. 1999. Movements of Tiger sharks (Galeocerdo cuvier)in coastal Hawaiian waters. Mar. Biol. 134: $665-673$.

Hooker, S.K., and R.W. Baird. 1999. Deep-diving behaviour of the northern bottlenose whale, Hyperoodon ampullatus (Cetacea: Ziphiidae). Proc. Roy. Soc. Lond. B 266: 671-676.

Jepson, P.D., M. Arbelo, R. Deaville, I.A.P. Patterson, P. Castro, J.R. Baker, E. Degollada, H.M. Ross, P. Herraez, A.M. Pocknell, F. Rodriguez, F.E. Howie, A. Espinosa, R.J. Reid, J.R. Jaber, V. Martin, A.A. Cunningham, and A. Fernandez. 2003. Gas-bubble lesions in stranded cetaceans. Nature (Lond.) 425: 575-576.

Johnson, M., P.T. Madsen, W.M.X. Zimmer, N. Aguilar de Soto, and P.L. Tyack. 2004. Beaked whales echolocate on prey. Proc. Roy. Soc. B. 271 (Biol. Lett. Supp. 6): S383-S386.

Lima, S.L., and P.A. Bednekoff. 1999. Temporal variation in danger drives antipredator behavior: the predation risk allocation hypothesis. Am. Nat. 153: $649-659$.

Long, D.J., and R.E. Jones. 1996. White shark predation and scavenging on cetaceans in the eastern North Pacific 0cean. Pages 293-307 In A.P. Klimley and D.G. Ainley (eds.) Great white sharks: the biology of Carcharodon carcharias. Academic Press, San Diego.

Lowe, C.G., B.M. Wetherbee, G.L. Crow, and A.L. Tester. 1996. Ontogenetic dietary shifts and feeding behavior of the tiger shark, Galeocerdo cuvier, in Hawaiian waters. Env. Bio. Fish. 47: 203-211.

MacLeod, C.D., M.B. Santos, and G.J. Pierce. 2003. Review of data on diets of beaked whales: evidence of niche separation and geographic segregation. J. Mar. Biol. Assoc. U.K. 83: 651-665.

McSweeney, D.J., R.W. Baird, and S.D. Mahaffy. 2007. Site fidelity, associations and movements of Cuvier's (Ziphius cavirostris) and Blainville's (Mesoplodon densirostris) beaked whales off the island of Hawai‘i. Mar. Mamm. Sci. 23: 666-687. 
Mead, J.G. 1989. Beaked whales of the genus Mesoplodon. Pages 349-430 In S.H. Ridgway and R. Harrison (eds.) Handbook of marine mammals. Academic Press, London.

Moretti, D., N. DiMarzio, R. Morrissey, J. Ward, and S. Jarvis. 2006. Estimating the density of Blainville's beaked whale (Mesoplodon densirostris) in the Tongue of the Ocean (TOTO) using passive acoustics. Oceans 2006: 1-5.

Norris, K.S., B. Würsig, R.S. Wells, M. Würsig, S.M. Brownlee, C.M. Johnson, and J. Solow. 1994. The Hawaiian spinner dolphin. University of California Press, Berkeley.

Notarbartolo-di-Sciara, G. 1987. Killer whales, orcinus orca, in the Mediterranean Sea. Mar. Mamm. Sci. 3: 356-360.

Papastamatiou, Y.P., B.M. Wetherbee, C.G. Lowe, and G.L. Crow. 2006. Distribution and diet of four species of carcharhinid shark in the Hawaiian Islands: evidence for resource partitioning and competitive exclusion. Mar. Ecol. Prog. Ser. 320: 239-251.

Perryman, W.L., M.A. Donahue, J.L. Laake, and T.E. Martin. 1999. Diel variation in migration rates of eastern Pacific gray whales measured with thermal imaging sensors. Mar. Mamm. Sci. 15: 426-445.

Railsback, S.F., B.C. Harvey, J.W. Hayse, and K.E. LaGory. 2005. Tests of theory for diel variation in salmonid feeding activity and habitat use. Ecology 86: 947-959.

Rommel, S.A., A.M. Costidis, A. Fernandez, P.D. Jepson, D.A. Pabst, W.A. McLellan, D.S. Houser, T.W. Cranford, A.L. VanHelden, D.M. Allen, and N.B. Barros. 2006. Elements of beaked whale anatomy and diving physiology and some hypothetical causes of sonar-related stranding. J. Cet. Res. Manage. 7: 189-209.

Santos, M.B., V. Martin, M. Arbelo, A. Fernández, and G.J. Pierce. 2007. Insights into the diet of beaked whales from the atypical mass stranding in the Canary Islands in September 2002. J. Mar. Bio. Ass. U.K. 87: 243251.

Southall, B., I. Boyd, P. Tyack, and D. Wartzok. 2007. Deep-diving odontocetes behavioral response study (BRS). Presentation at the conference on the effects of noise on aquatic life, Nyborg, Denmark, August 13-17, 2007.

Strong, W.R., Jr. 1996. Shape discrimination and visual predatory tactics in white sharks. Pages 229-240 In A.P. Klimley and D.G. Ainley (eds.) Great white sharks: the biology of Carcharodon carcharias. Academic Press, San Diego.

Tricas, T.C., and J.E. McCosker. 1984. Predatory behavior of the white shark (Carcharodon carcharias), with notes on its biology. Proc. Cal. Acad. Sci. 43: 221-238.

Tyack, P.L., M. Johnson, N.A. Soto, A. Sturlese, and P.T. Madsen. 2006. Extreme diving of beaked whales. J. Exp. Biol. 209: 4238-4253. 
Watanabe, H., T. Kubodera, M. Moku, and K. Kawaguchi. 2006. Diel vertical migration of squid in the warm core ring and cold water masses in the transition region of the western North Pacific. Mar. Ecol. Prog. Ser. 315: 187-197.

Weng, K.C., A.M. Boustany, P. Pyle, S.D. Anderson, A. Brown, and B.A. Block. 2007. Migration and habitat of white sharks (Carcharodon carcharias) in the eastern Pacific Ocean. Mar. Biol. 227: in press.

Wetherbee, B.M., G.L. Crow, and C.G. Lowe. 1996. Biology of the Galapagos shark, Carcharhinus galapagensis, in Hawai'i. Env. Biol. Fish. 45: 299310 .

Zimmer, W.M.X., and P.L. Tyack. 2007. Repetitive shallow dives pose decompression risk in deep-diving beaked whales. Mar. Mamm. Sci. 23: 888925 . 
Table 1. Comparison of diving parameters for Blainville's beaked whales with both day- and night-time dive data $(n=6)$. SDs calculated from a single value for each individual. Ranges shown using a single value for each individual.

\begin{tabular}{|c|c|c|c|c|c|c|}
\hline \multirow[t]{2}{*}{ Variable } & \multicolumn{2}{|l|}{ Day: } & \multicolumn{2}{|c|}{ Night: } & \multirow{2}{*}{$\begin{array}{l}\text { \% change from } \\
\text { day to night }\end{array}$} & \multirow{2}{*}{$\begin{array}{l}\text { Significance } \\
\text { (paired t-test) }\end{array}$} \\
\hline & Grand Mean (SD) & Range & Grand Mean (SD) & Range & & \\
\hline Longest time $<50 \mathrm{~m}$ (min) & $45.06(31.02)$ & $14.9-98.8$ & $91.73(32.30)$ & $60.5-153.7$ & 50.9 & 0.036 \\
\hline$\%$ time $<50 \mathrm{~m}$ & $38.16 \quad(5.06)$ & $33.7-53.4$ & $56.95(12.36)$ & $41.1-72.7$ & 33.0 & $\odot .0 \odot 4$ \\
\hline$\%$ time >500 m & $(2.82)$ & $18 \cdot 3-24.0$ & $28.2 \quad(6.3)$ & $20.5-37.4$ & 22.5 & 0.098 \\
\hline$\%$ time between 22 and $72 \mathrm{~m}$ & $(2.76)$ & $9.19-17.25$ & $21.21(13.04)$ & $9.01-39.37$ & 36.2 & 0.142 \\
\hline Dive rate (\# dives/h) 100-600 m & $(0.54)$ & $\odot .86-2.37$ & $0.26 \quad(0.20)$ & $\odot . \odot-\odot .53$ & -511.5 & 0.001 \\
\hline Dive rate (\# dives/h) >800 m & $(0.09)$ & $\odot .30-0.52$ & $(0.09)$ & $0.33-0.56$ & 17.4 & 0.253 \\
\hline Mean duration (min) $>800 \mathrm{~m}$ & $(3.61)$ & $51.0-60.2$ & $(5.10)$ & $43.3-57.5$ & -5.9 & 0.118 \\
\hline Mean depth $(\mathrm{m})>800 \mathrm{~m}$ & $1099 \quad(183.8)$ & 896-1409 & $1052 \quad(114.6)$ & $872-1182$ & -4.5 & $\odot .493$ \\
\hline Max duration (min) & $61.06 \quad(4.85)$ & $53.07-68.2$ & $61.47(12.4)$ & $48.87-83.38$ & $\odot .7$ & $\odot .867$ \\
\hline Max depth (m) & $1254.5(249.96)$ & 985-1599 & $1237.7(194.42)$ & $903-1443$ & -1.35 & 0.931 \\
\hline Ascent rate $(\mathrm{m} / \mathrm{sec})>800 \mathrm{~m}$ & $0.68 \quad(0.12)$ & $\odot .50-0.83$ & $0.78 \quad(0.11)$ & $\odot .63-0.92$ & 12.8 & $\odot .248$ \\
\hline Descent rate $(\mathrm{m} / \mathrm{sec})>800 \mathrm{~m}$ & $(0.13)$ & $1.36-1.67$ & $(0.20)$ & $1.13-1.67$ & -4.9 & 0.127 \\
\hline
\end{tabular}

Table 2. Comparison of diving parameters for Cuvier's beaked whales with both day- and night-time dive data ( $n=2$ ). SDs calculated with a single value for each individual. Ranges shown using a single value for each individual.

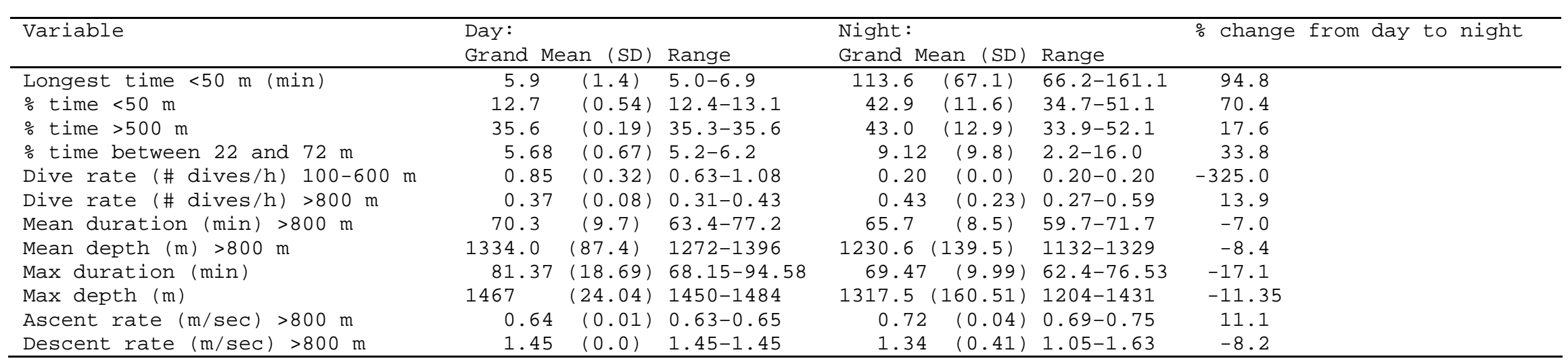



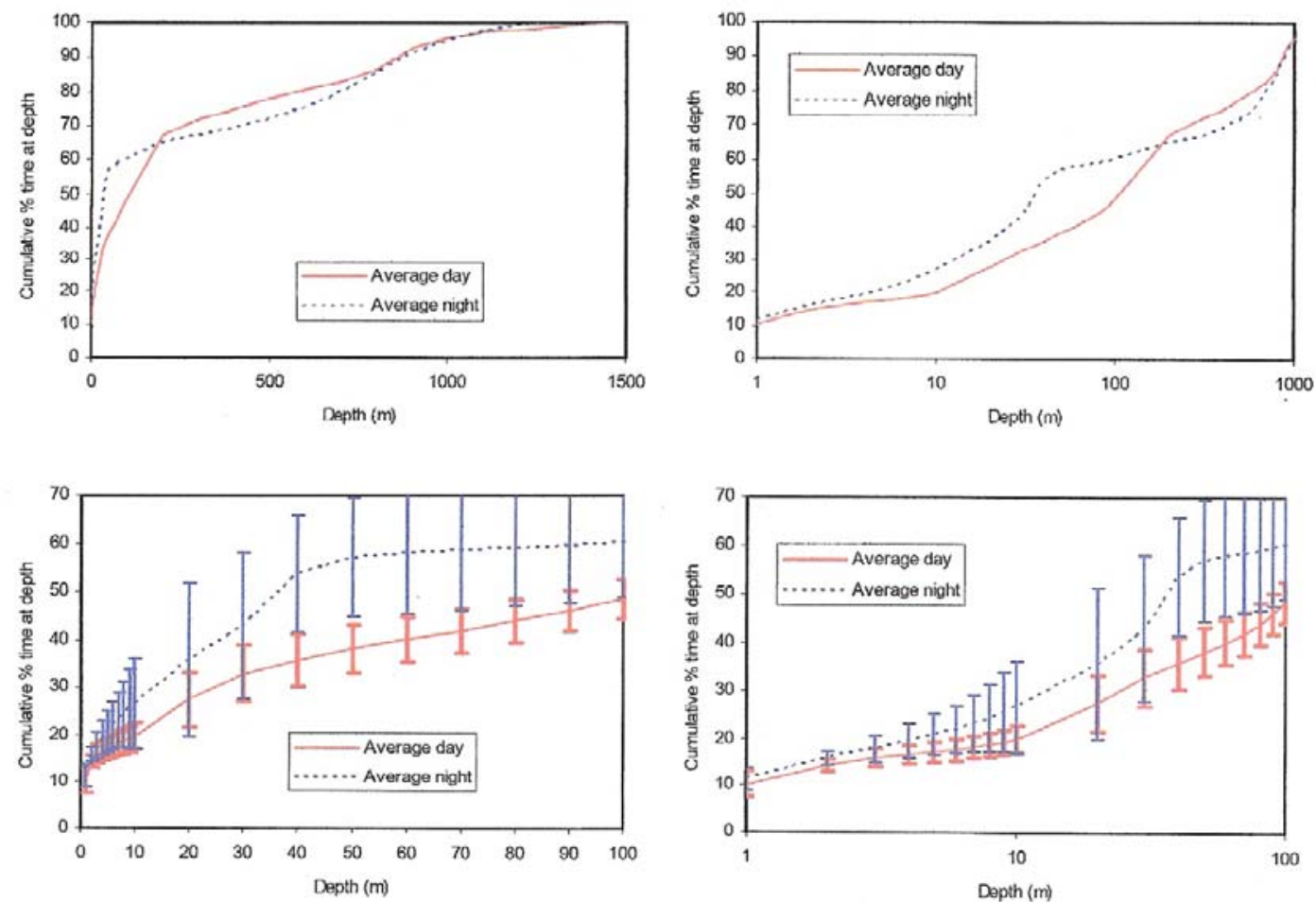

Fig. 1. Cumulative percentage of time at or less than specified depths during the day (solid red line) or at night (dashed blue line) for all six Blainville's beaked whales with both day- and night-time data. Upper left panel shows entire water column. Upper right panel shows top 1,000 $\mathrm{m}$ on a log scale. Lower panels show the top $100 \mathrm{~m}$ (linear and log scales) with bars representing +/-1 SD. SDs calculated from a single value for each individual. 

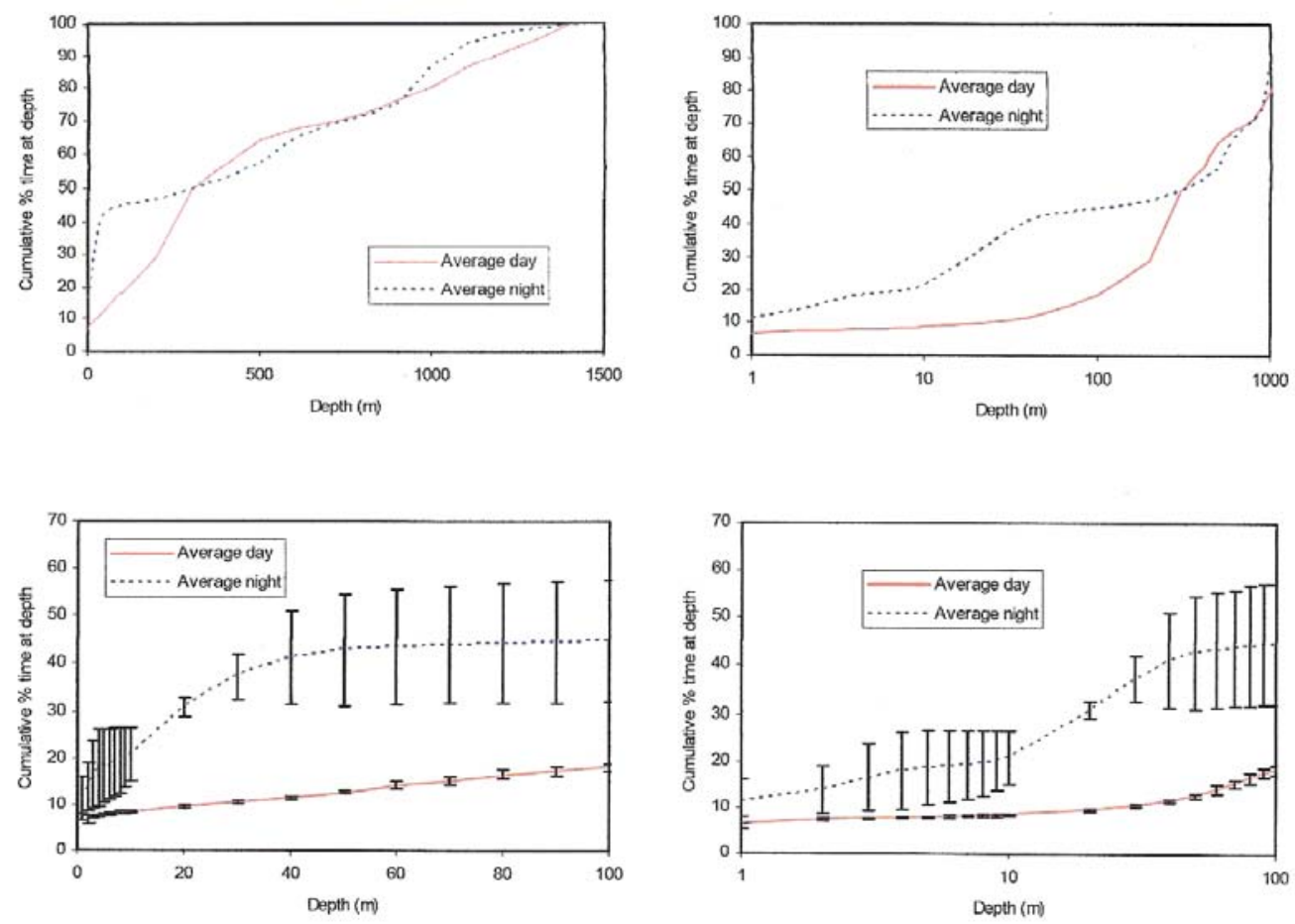

Fig. 2. Cumulative percentage of time at or less than specified depths during the day (solid red line) or at night (dashed blue line) for all two Cuvier's beaked whales with both day- and night-time data. Upper left panel shows entire water column. Upper right panel shows top $1,00 \odot \mathrm{m}$ on a $\log$ scale. Lower panels show the top $100 \mathrm{~m}$ (linear and log scales) with bars representing $+/-1$ SD. SDs calculated from a single value for each individual. 


\section{Initial Distribution List}

1. Defense Technical Information Center 8725 John J. Kingman Rd., STE 0944

Ft. Belvoir, VA 22060-6218

2. Dudley Knox Library, Code 013 Naval Postgraduate School

Monterey, CA 93943-5100

3.

Erin Oleson

Scripps Institution of Oceanography

University of California

La Jolla, CA

4. John Hildebrand

Scripps Institution of Oceanography

University of California

La Jolla, CA

5. John Calambokidis

Cascadia Research Collective

Olympia, WA

6. Greg Schorr

Cascadia Research Collective

Olympia, WA

7. Erin Falcone

Cascadia Research Collective

Olympia, WA

8. Ching_Sang Chiu

Office of Naval Research

washington, DC

9. Curtis A. Collins

Naval Postgraduate School

Monterey, CA

10. Thomas A. Rago

Naval Postgraduate School

Monterey, CA

11. Tetyana Margolina

Naval Postgraduate School

Monterey, CA

12. Chris Miller

Naval Postgraduate School

Monterey, CA

13. John Joseph

Naval Postgraduate School

Monterey, CA 
15.

Frank Stone

N45

Washington, D.C.

16.

Jay Barlow

Southwest Fisheries Science Center, NOAA La Jolla, CA

17

CAPT Ernie Young, USN (Ret.)

18.

Dale Liechty

N45

Washington, D.C.

19. Dave Mellinger

Oregon State University

Newport, OR

20.

Kate Stafford

Applied Physics Laboratory

University of Washington

Seattle, CA

21.

Sue Moore

NOAA at Applied Physics Laboratory

University of Washington

Seattle, WA

22. Andrew Read

Duke University Marine Laboratory

Beaufort, NC

23.

Elliott Hazen

Duke University Marine Laboratory

Beaufort, NC

24.

Lucie Hazen

Duke University Marine Laboratory

Beaufort, NC

25.

Lesley Thorne

Duke University Marine Laboratory

Beaufort, NC

26.

Ben Best

Duke University

Durham, NC

27.

Patrick Halpin

Duke University

Durham, NC 
28.

Petr Krysl

University of California

La Jolla, CA

29. Mark McDonald

Whale Acoustics

Bellvue, co

30.

Ted Cranford

Quantitative Morphology Consulting, Inc. AND

San Diego State University

San Diego, CA

31.

Robin Baird

Cascadia Research Collective

Olympia, WA

32.

Daniel L. Webster

Wild Whale Research Foundation

Holualoa, HI

33. Daniel J. McSweeney

Wild Whale Research Foundation

Holualoa, HI

34. Monique Fargues

Naval Postgraduate School

Monterey, CA

35. LCDR Mike Loomis

Naval Postgraduate School

Monterey, CA

36.

LTJG Jessica Mohamed

Naval Postgraduate School

Monterey, CA

37. LT Christian Jensen

Naval Postgraduate School

Monterey, CA 